\title{
天然ガス予混合圧縮自己着火機関の過給による性能改善*
}

\author{
佐 古 孝 弘*1, 中 井 俊 作 ${ }^{* 2}$ \\ 守 家 浩 二*1, 飯 田 訓 正 ${ }^{* 3}$ \\ Improvement of Performance in a Natural-Gas Fueled \\ Homogeneous Charge Compression Ignition Engine with Supercharged \\ Takahiro SAKO*4, Shunsaku NAKAI, \\ Koji MORIYA and Norimasa IIDA \\ ${ }^{* 4}$ Osaka Gas Co., LTD, 6-19-9 Torishima, Konohana-ku, Osaka, 554-0051 Japan

\begin{abstract}
A supercharged natural gas compression ignition engine has been tested to confirm the performance as well as the exhaust gas characteristics. The supercharging improved the thermal efficiency through the improvement of the combustion efficiency, the mechanical efficiency, and the cooling loss. The indicated thermal efficiency becomes the highest when in-cylinder temperature is about $1700 \mathrm{~K}$, due to the improved combustion efficiency and the decrease of cooling loss. The supercharging also reduces the $\mathrm{NO}_{x}$ emission. This is because the maximum temperature is kept low while the combustion efficiency is kept high compared with the natural aspiration. The pressure at auto-ignition inceased in case the boost pressure is raised. However, the auto-ignition temperature is the same and $1000 \sim 1030 \mathrm{~K}$
\end{abstract}

Key Words: Ignition, Internal Combustion, Premixed Combustion, Natural Gas, HCCI, PCCI, Boost

1. はじめに

予混合圧縮自己着火(HCCI)機関はディーゼル機関の NOx 排出量低減やカソリン機関における低出力域の効 率を向上できる可能性がある(1) (3). また, 供給安定性お よび優れた環境性から天然カスを燃料とする HCCI 機 関の研究も進められている(4) (8). これまでの研究による と, HCCI 機関は失火あるいは燃焼変動とノックによっ て運転可能な負荷範囲が限定されることが報告されて いる. つまり $\mathrm{HCCl}$ 機関は, 比較的高い平均有効圧力で 運転ができれば回転速度一定で定常運転を行ない, 高い 熱効率と低い NOx 排出量を求められるようなコージェ ネレーションなどの用途に対しては有利であると考え られる. 天然カス HCCI 機関の運転範囲拡大に関しては, 化学反応にもとづいた着火時期の制御(4)や筒内直接噴 射によって燃料に不均一性を付与する方法(5)などが検 討されている.さらに，EGR を適用した燃焼期間の制

* 原稿受付 2004 年 9 月 27 日.

*1 正員, 大阪ガス(株) (554-0051 大阪市此花区西島 6-199).

*2 大阪ガス (株).

*3 正員, 穈應義塾大学理工学部( 223-8522 横浜市港北区日 吉 3 14-1).

E-mail : sako@osakagas.co.jp
御(7)(8)などの試みがなされている. しかし，いずれも着 火時期や燃焼期間を制御できることは示されているが, 平均有効圧力の向上に関してはなお改善の余地がある. 本研究では, 天然カススを燃料とする HCCI 機関に排気夕 一ビン過給を適用することを想定して, 過給機効率を模 擬した場合の性能および排気特性を詳細に調査する.こ れにもとづき過給による平均有効圧力の向上, 熱効率の 向上の可能性を明らかにする. また, 無過給と過給の性 能を比較することで過給による性能改善の原因につい ても検討する.

Table1 Engine specifications

\begin{tabular}{ll}
\hline Engine type & Single cylinder Water cooled \\
Bore $\times$ stroke & $112 \mathrm{~mm} \times 115 \mathrm{~mm}$ \\
Displacement & $1,132 \mathrm{~cm}^{3}$ \\
Compression ratio & 17 \\
Boost pressure(gauge) & $50 \mathrm{kPa}, 75 \mathrm{kPa}, 100 \mathrm{kPa}$ \\
& $125 \mathrm{kPa}, 150 \mathrm{kPa}$ \\
Combustion chamber & $\mathrm{Flat}$ \\
Intake air temperature & $\sim 573 \mathrm{~K}$ \\
& (with an electric heater) \\
\hline
\end{tabular}




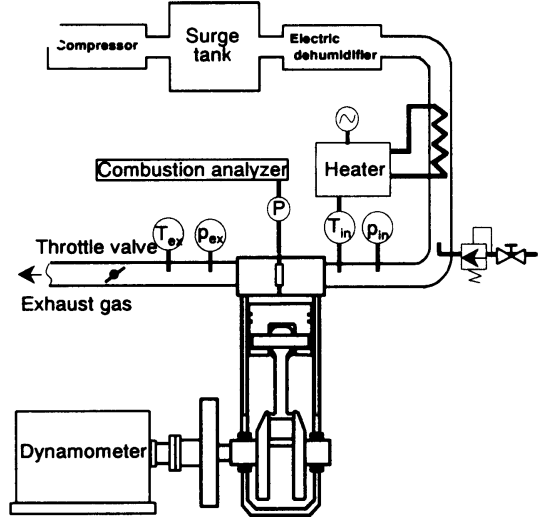

Fig. 1 Experimental setup

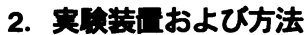

試験に用いたベースエンジンは無過給水冷単気筒 4 サイクル直接噴射式ディーゼル機関であり, HCCI 試験 のために一部変更を加えた. 試験に用いた単気筒試験機 の主要諸元を表 1 に示す. 主な変更点は燃焼室ならびに 機関圧縮比である.

ベースエンジンの燃焼室はトロイダルタイプである が, 燃焼室内の流動の影響を低減するためにフラットタ イプに変更した. また, 機関圧縮比はベースエンジンに おいて 16.3 であるが本研究では 17.0 とした.

図 1 に試験装置の概略を示す. 吸気系には電気ヒータ (竹綱製作所 S-6T)を設置した. 吸気温度はシリンダヘッ ドから $100 \mathrm{~mm}$ 上流の温度を $\mathrm{J}$ 熱電対で計測し, 電気ヒ 一夕出力を制御することで所定値に設定した. 吸入空気 は回転容積型オイルフリー圧縮機(アネスト岩田 ZTD-220J)で 0.7MPa に加圧し, 冷凍式圧縮空気除湿器 (アネスト岩田 RDG-370)で除湿した後, レギュレータに て減圧し所定の圧力に調整した. 供給空気の圧力は静電 容量式圧力計(コスモ計器 DP-330), 排気圧力についても 静電容量式圧力計(桜エンドレス PMP-635)にて計測し た. また, 排気系には背圧を付与するためにバタフライ バルブ(巴バルブ 337Y)を取り付けた. 試験に用いた燃 料は $13 \mathrm{~A}$ 天然ガス(代表組成: $\mathrm{CH}_{4} 88 \%, \mathrm{C}_{2} \mathrm{H}_{6} 6 \%, \mathrm{C}_{3} \mathrm{H}_{8}$ $4 \%, \mathrm{C}_{4} \mathrm{H}_{10} 2 \%$ )であり然料はレギュレータにより $0.7 \mathrm{MPa}$ を 0.4MPa に隇圧した後, シリンダヘッドより $1000 \mathrm{~mm}$ 上流の吸気管内に設置したノズルから連続供給した. 供 給燃料流量は熱線式質量流量制御計(STEC SEC-4600)に より流量制御を行い, また, 空気流量は首流型空気流量 計(司測研 LFE-25B)にて計測した.

筒内圧力は水冷圧電式圧力変換器(KISTLER 6061B) にてロータリーエンコーダから得られるクランク角度 信号および TDC 信号により燃焼解析装置(小野測器
DS-9100)の内部で発生されるクロック信号に同期させ て $0.1^{\circ} \mathrm{CA}$ 毎に計測した. 排気中の窒素酸化物 $\mathrm{NO}_{\mathrm{x}}$ は 化学発光分析計, 一酸化炭素 CO および二酸化炭素 $\mathrm{CO}_{2}$ は赤外線分析計, 全炭化水素 THC は加熱型 FID 分 析計にて $\mathrm{CH}_{4}$ 換算值として計測, 酸素 $\mathrm{O}_{2}$ は磁気圧型に てそれぞれ計測した(堀場製作所 MEXA9100D).なお, 運転における燃焼変動限界を図示平均有効圧力のサイ クル変動率が $3 \%$ 付近と定めた. ノック限界は筒内圧力 波形をバンドパスフィルタにて処理することで得られ る圧力振幅をノック強度とし, その最大值の平均が $50 \mathrm{kPa}$ を越える当量比をノック限界と定めた.

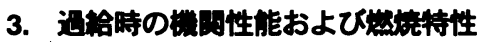

外部圧縮機を用いて過給圧力が機関性能および排気 特性，燃焼特性値に与える影響を調べた。過給圧力は $50 \mathrm{kPa}$ から $150 \mathrm{kPa}$ の範囲で五点設定した. また, 実験 は排気系に取り付けたバタフライバルブの開度を調整 することによって, 過給機効率 $65 \%$ を模擬した. なお, 過給機効率は作動流体の比熱比を 1.4 一定, コンプレッ サ入り口圧力を大気圧, タービンは大気圧まで膨張する と仮定して, 計測した吸排気圧力, 排気温度, 大気温度 などよりコンプレッサ仕事とタービン仕事を算出して 求めた.

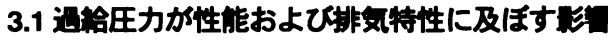

機関圧縮比 $\varepsilon=17$, 機関回転速度 $n_{\mathrm{e}}=1200 \mathrm{rpm}$, 機関冷 却水出口温度 $353 \mathrm{~K}$ および吸気温度 $T_{\text {in }}=423 \mathrm{~K}$, 模擬過給 機効率 $\eta_{\mathrm{T} / \mathrm{C}}=65 \%$ に固定して過給圧力 $p_{\text {in }}$, 当量比 $\phi$ を変化

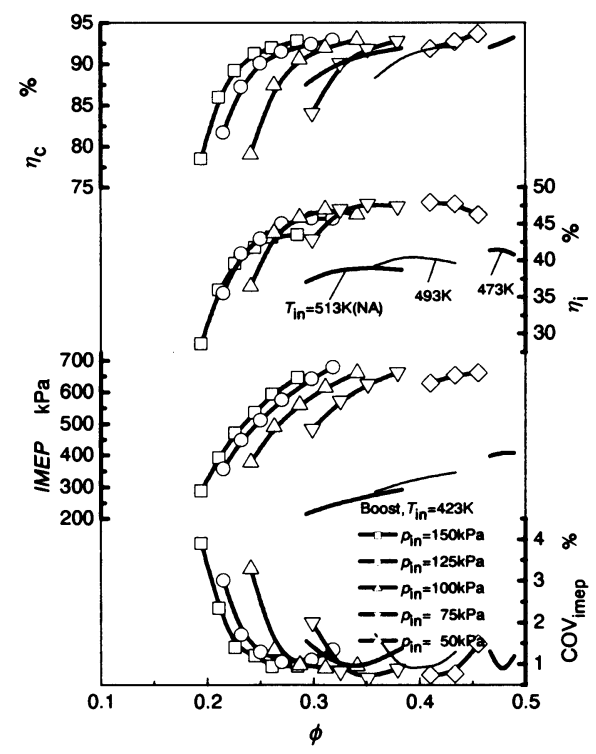

Fig. 2 Effect of boost pressure on engine performance 
させた. 図 2 に, $p_{\text {in }}$ および $\phi$ を変化させた場合における 排気中の THC ならびに CO および然料流量より算出し た燃焼効率 $\eta_{\mathrm{c}}$, 図示熱効率 $\eta_{\mathrm{i}}$ および図示平均有効圧力 $I M E P$, 図示平均有効圧力の変動率 $C O V_{\text {imep }}$ を示す. な お，図には比較のため無過給機関 NA における， $\varepsilon=17$, $T_{\text {in }}=473,493,513 \mathrm{~K}$ の運転データをあわせて示す. $p_{\text {in }}$ を増すと燃焼変動限界ならびにノック限界は, 低い $\phi$ 側 へ移動する. $\eta_{\mathrm{c}}$ は同じ $\phi$ で比較すると, $p_{\mathrm{in}}$ が増加すると 改善される傾向を示す. 最大 $\eta_{\mathrm{c}}$ は, $p_{\text {in }}$ および $\phi に$ 依存せ ず, おおむね $93 \%$ 一定となり, NA の最大 $\eta_{\mathrm{c}}$ よりわずか に改善される.IMEP は, 同じ $\phi$ であれば, $p_{\text {in }}$ が高いほ ど向上するが, 運転可能最大 IMEP は $p_{\text {in }}$ に依存せず

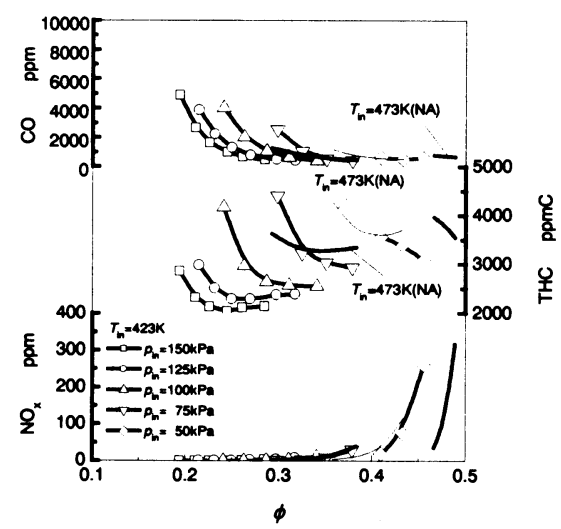

Fig. 3 Effect of boost pressure on exhaust emission

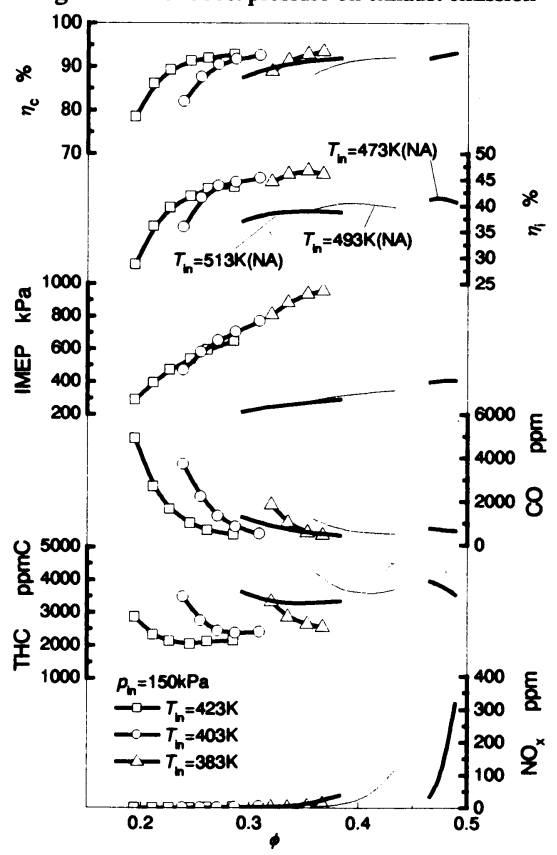

Fig. 4 Effect of intake air temperature on engine performance and emission
$650 \mathrm{kPa}$ 程度である. 一方で, NAにおける運転可能最大 IMEP は $400 \mathrm{kPa}$ 程度であり, 過給することによって運 転可能最大 IMEP は向上する. $\eta_{\mathrm{i}}$ は過給すると向上し, $\mathrm{NA}$ と比較するとおおむね 7 ポイント程度改善される. 過給による $\eta_{\mathrm{i}}$ の改善は, $\eta_{\mathrm{c}}$ の向上が一つの原因として考 えられるが, 同じ $\eta_{\mathrm{c}}$ であっても, $\eta_{\mathrm{i}}$ が高くなる傾向があ り, その他の要因が存在することが示唆される.

図 3 にCO, THC, NOx 排出濃度の $p_{\text {in }}$ およびфに対す る変化を示す. $\mathrm{CO}$ および $\mathrm{THC}$ の排出濃度は $p_{\text {in }}$ を高め るか, $\phi$ を高めると減少する. NOx は NA, 過給によら ず， $\phi$ を高めると增加する傾向を示す.

以上は， $T_{\text {in }}$ を固定した場合の性能および排気特性で

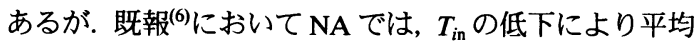
有効圧力が向上することが明らかになっている. そこで, $p_{\text {in }}$ を固定し $T_{\text {in }}$ を変化させた場合の性能および排気特性 に関して調査した. 図 4 に, $p_{\text {in }}$ を $150 \mathrm{kPa}$ に固定して $T_{\text {in }}$ を変化させた場合の $\eta_{\mathrm{c}}, \eta_{\mathrm{i}}, I M E P, \mathrm{CO}, \mathrm{THC}, \mathrm{NOx}$ 排 出濃度の変化を饾対して示す. なお, 戝には比較のた めに $\varepsilon=17, \mathrm{NA}$ のデータをあわせて示す. $T_{\text {in }}$ が低下する と運転範囲が高い $\phi$ 側へ移動し, 運転可能最大 IMEP は 向上する. $p_{\text {in }}=150 \mathrm{kPa}$ にて運転できる, $T_{\text {in }}$ の下限は $383 \mathrm{~K}$ であり運転可能最大 IMEP は $950 \mathrm{kPa}$ となる. また, 排 出物に関して, NOx に着目すると, $p_{\text {in }}=150 \mathrm{kPa}$ の場合い ずれの $T_{\text {in }}$ においても排出量は極めて低い.これは運転 可能な $\phi$ 範囲が希薄側に限定されることによる.

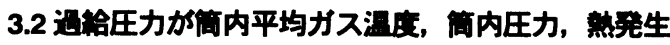

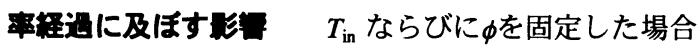
について熱発生率経過などについて検討を加える. 図 5 に熱発生率および筒内平均ガス温度より算出した燃焼 特性値を示す。ここで， $\theta_{\mathrm{ig}}$ は熱発生の開始時期として 定義した着火時期, $\theta_{10-90}$ は熱発生量が総発生熱量の $10 \%$ から 90\%に達するまでの期間として定義した燃焼期間, $(d q / d \theta)_{\max }$ は熱発生率の最大值である. $\theta_{\mathrm{ig}}$ は, $p_{\text {in }}$ および $\phi$ を增すと早期化する傾向を示す. $\theta_{10-90}$ は, 同一の $\phi$ では, $p_{\text {in }}$ が高くなると短期化する傾向を示すがノック限界に おいては, $p_{\text {in }}$ によらず, ほぼ一定となる. $(d q / d \theta)_{\text {max }}$ は, $p_{\text {in }}$ およ゙ $\phi$ を增すと上昇し，短期間で急激な熱発生とな る. 図 6 には燃焼経過を検討するために, $T_{\text {in }}=423 \mathrm{~K}, p_{\text {in }}$ $=75 \mathrm{kPa}, 100 \mathrm{kPa}$ および $150 \mathrm{kPa}$ における $\phi=0.3$ 付近の简 内圧力 $p$, 理想気体の状態式から求めた筒内平均カス温 度 $T$, 冷却損失の補正を施していない単位混合気質量あ たりの熱発生率 $d q / d \theta$ 履歴の 200 サイクル平均波形を示 す. 図には比較のため NA, $T_{\text {in }}=513 \mathrm{~K}, \phi=0.29$ のデータ をあわせて示す. 図より, 最大筒内圧力は $p_{\text {in }}$ に依存し, 過給圧力比分だけ上昇する. T の最大值は NA, 過給に よらず着火時期によって決まり, 着火時期が早期化する 


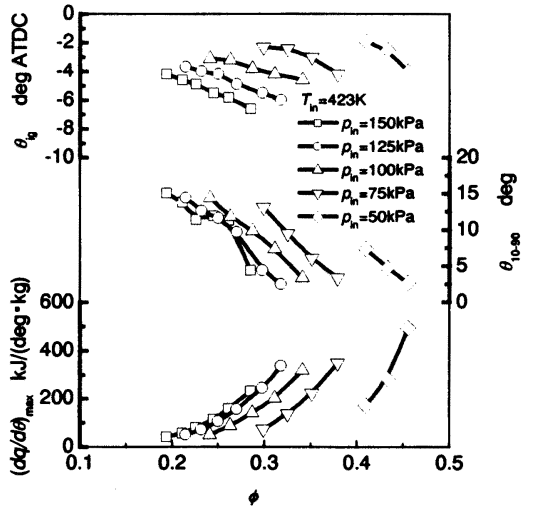

Fig. 5 Effect of boost pressure on combustion characteristics

ほど上昇する．また， $p_{\text {in }}$ を増すと熱発生の開始は早期 化し, 熱発生期間が短くなり, 熱発生率の最大值も上昇 する. このように $p_{\text {in }}$ を増すと着火時期が早期化し速や かに燃焼反応が進行するのは燃料および酸素密度が高 くなることによる燃焼反応速度の増加が原因であると 考える. つぎにそれぞれの $p_{\text {in }}$ における着火時の温度お よび圧力を比較する. 図 7 に, $T_{i n}=423 \mathrm{~K}, \phi=0.30$ 近辺に おける, 筒内圧力 $p$ および筒内平均ガス温度 $T$ を示す. なお, 図中は着火位置を示す. $p_{\text {in }}$ が $75 \mathrm{kPa}$ から $150 \mathrm{kPa}$ まで変化すると着火時の圧力 $p_{\mathrm{ig}}$ は, およそ $6.5 \mathrm{MPa}$ から $9.0 \mathrm{MPa}$ まで変化し, $p_{\text {in }}$ を高めると上昇する傾向を示す. 一方で, 自己着火温度は, $p_{\mathrm{ig}}$ が $0.3 \mathrm{MPa}$ から $0.9 \mathrm{MPa}$ ま で変化することで約 $1000 \mathrm{~K}$ から $1030 \mathrm{~K}$ にまでしか変化 しない.このことから， $p_{\text {in }}$ が自己着火温度におよぼす 影響はごくわずかであると考えられる.

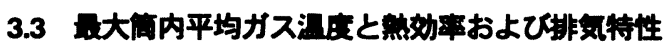

既報(6)において, NA 運転の筒内平均ガス温度は燃 焼効率や NOx 排出量に与える影響が大きいことを明ら かにし, 温度制御の重要性を示した. ここで過給運転の 最大筒内平均カス温度 $T_{\text {max }}$ と燃焼効率および排出物に ついて整理する. 図 8 に, $\eta_{\mathrm{c}}$ およびCO, NOx 排出濃度 の変化を $T_{\text {max }}$ に対して示す. NA では, $T_{\text {max }}$ が高くなる と $\eta_{\mathrm{c}}$ は向上する. しかしながら過給の場合は, $T_{\text {max }}$ が高 くなることに加えて, $p_{\text {in }}$ が增すことでも $\eta_{\mathrm{c}}$ は向上する. NOx 排出量は, NA, 過給いずれも $T_{\text {max }}$ に強く依存し, $1800 \mathrm{~K}$ 以上で急激に增加する． $\eta_{\mathrm{c}}$ を $90 \%$ 以上確保する ための $T_{\max }$ は, NA ではおおむね $1700 \mathrm{~K}$ であるが, $p_{\mathrm{in}}=150 \mathrm{kPa}$ では $1500 \mathrm{~K}$ 程度であり $200 \mathrm{~K}$ 程度低温側に移 動する.

ここで示したように $T_{\max }$ の範囲が 1500 1800K であ れば $\eta_{\mathrm{c}}$ も高く, NOx 排出量も極めて低い状態で運転す ることが可能となる. つまり, その温度範囲において高 い熱効率を得ることできれば高い効率, 低い NOx 排出

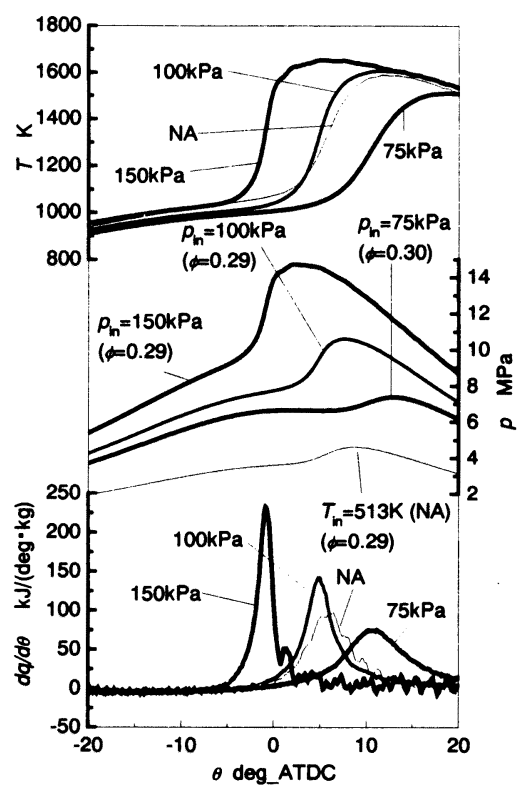

Fig. 6 Courses of heat release rate, in-cylinder pressure and temperature $(\phi \doteqdot 0.30)$

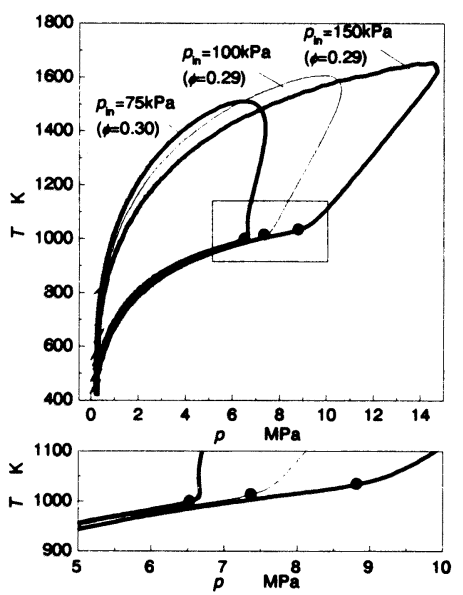

Fig. 7 T-P diagram of supercharged HCCl combustion

量の運転が可能となる. そこで, 熱効率と $T_{\max }$ の関係に ついて検討する. 図 9 に, $T_{\text {in }}, p_{\text {in }}$ を変化させた場合の 圧縮, 膨張行程における図示熱効率 $\eta_{\mathrm{i}}$ 'を $T_{\max }$ について 示す. なお, 比較のため NA, $\varepsilon=17$ の結果を図示する. 過給の場合 $\eta_{\mathrm{i}}{ }^{\prime}$ は $T_{\text {max }}$ と強い相関があり, $p_{\text {in }}$ や $T_{\text {in }}$ などの 吸気条件を変化させても $T_{\text {max }}=1700 \mathrm{~K}$ 付近で最大 $\eta_{i}{ }^{\prime}$ が得 られる.この現象は燃焼効率と冷却損失が原因で生じて いると考えられる.つまり低い $T_{\text {max }}$ においては燃焼悪化 のため $\eta_{\mathrm{c}}$ が低下する傾向があるが, $p_{\text {in }}$ を増すと $\eta_{\mathrm{c}}$ が改 善されるとともに着火時期が早期化する. このため $\eta_{c}$ の向上と着火時期早期化による冷却損失の増加が相殺 


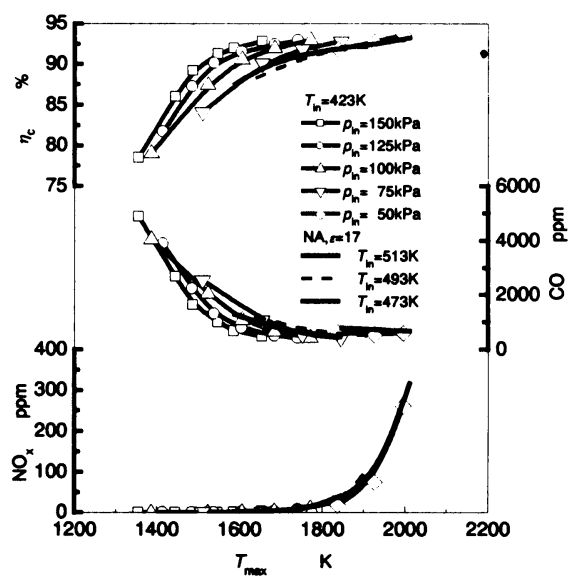

Fig. 8 Effect of maximum in-cylinder gas temperature on combustion efficiency, NOx and $\mathrm{CO}$ emission

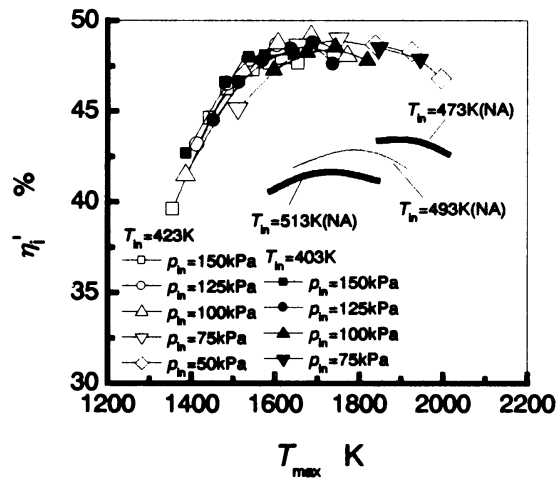

Fig. 9 Effect of maximum in-cylinder gas temperature and boost pressure on indicated thermal efficiency

され，いずれの吸気条件でもほぼ一定の $\eta_{i}{ }^{\prime}$ となる. $1700 \mathrm{~K}$ 以上では吸気条件によらず $\eta_{\mathrm{c}}$ はほぼ一定となる. そのため着火時期が早期化することによる冷却損失の 増加のみが作用する. このため, $1700 \mathrm{~K}$ 以上では $\eta_{\mathrm{i}}{ }^{\prime} か ゙$ 低 下する. 一方で, NA において $\eta_{\mathrm{c}}$ は $T_{\max }$ が高くなると向 上する. さらに $T_{\text {in }}$ の低下にともない着火時期は遅角化 し冷却損失が隇少する. これらは共に $\eta_{i}$ 向上の原因と なる. $T_{\text {max }}$ が高くなると冷却損失は增加するが $\eta_{c}$ 向上と 着火時期遅角化による冷却損失減少の相乗作用による $\eta_{i}^{\prime}$ の增加がそれを上回るため, NA では $T_{\text {max }}$ が上昇する と $\eta_{\mathrm{i}}^{\prime}$ が向上すると考える.

以上示した理由により過給では高い熱効率のもと, 極 めて低い NOx 排出濃度で運転が可能であると考える.

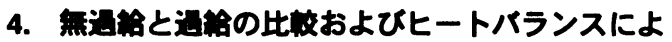

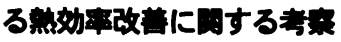

天然カスは然料特性により着火温度が高い. そのため 吸気加熱などにより圧縮端温度を増す必要がある. しか し, 吸気加熱にはエネルギーが必要となるためできる限

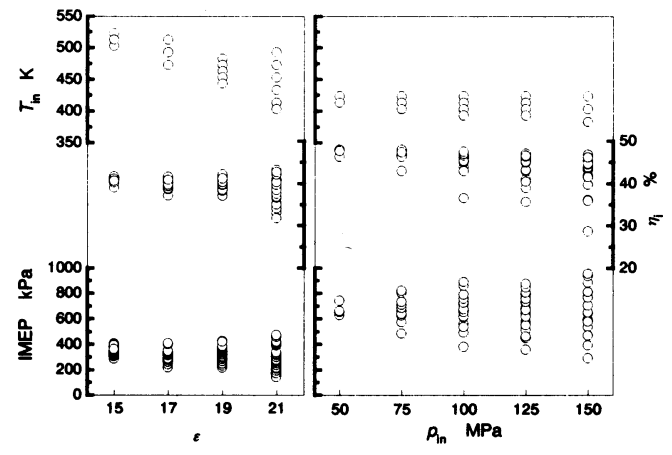

Fig. 10 Intake temperature and indicated thermal efficiency, indicated mean effective pressure with natural aspiration compared with supercharged

り低い吸気温度で運転できることが望ましい. 本章では, 無過給 NA と過給の運転範囲を比較することに加えて, 過給することによって熱効率が向上する原因をヒート バランスにより考察する.

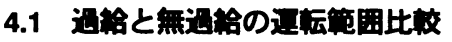
ここで NA と過給の運転範囲に関して整理する. 運転範囲として $T_{\text {in }}, \eta_{\mathrm{i}}$ およびIMEP に着目した. 図 10 に運転可能な, $T_{\text {in, }}, \eta_{i}, I M E P$ の変化を, $\varepsilon$ および $p_{\text {in }}$ に対して示す. な

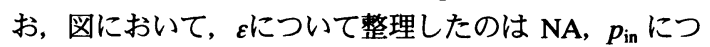
いて整理したものは過給, $\varepsilon=17$ である. なお図には運 転したすべての当量比におけるデータをプロットした. また, $T_{\text {in }}$ の上限は運転をおこなっていないだけであり 運転限界を示すものではない，NA では圧縮比が増すと 運転可能な $T_{\text {in }}$ の下限は拡大する. また, その変化は単 位 $\varepsilon$ あたり $15 \mathrm{~K}$ 程度である. 過給の場合は $p_{\text {in }}$ が $50 \mathrm{kPa}$ から $150 \mathrm{kPa}$ まで変化すると $T_{\mathrm{in}}$ の下限は $30 \mathrm{~K}$ 程度拡大 し, 無過給の同一 $\varepsilon$ で比べると $90 \mathrm{~K}$ 程度低い温度で運転 が可能である. 最大の $\eta_{\mathrm{i}}$ は過給することで 5 ポイント程 度向上する. さらに, 運転可能最大 IMEP は NA では 450kPa であるが過給では $950 \mathrm{kPa}$ 程度と大きく改善され る. 過給実験では過給機効率を模擬するために背圧を付 与する.これによる残留ガスの影響を考虑する必要はあ るが, $p_{\text {in }}$ が高まり燃焼反応速度が增すことによって低 い $T_{\text {in }}$ での運転が可能になったと考える.

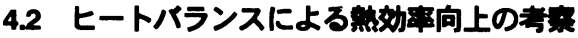

過給すると熱効率が向上する原因についてヒートバラ ンスを適用して考察する. ヒートバランスの算出は鶴島 ら (9)の方法に準じるが, 空気の定圧比熱を排気に適用し， 窒素酸化物生成反応による吸熱を取り扱わないことと した. 図 11 に NA, $T_{\text {in }}=473 \mathrm{~K}$ および $p_{\text {in }}=150 \mathrm{kPa}, T_{\text {in }}=383 \mathrm{~K}$ における最大効率点のヒートバランスを示す. 過給する ことによって, 未燃成分が有する熱量割合 $Q_{\mathrm{ub}}$ がわずか に減少し, 排気損失 $Q_{\mathrm{ex}}-Q_{\text {in }}$ は增加する. しかしながら, 


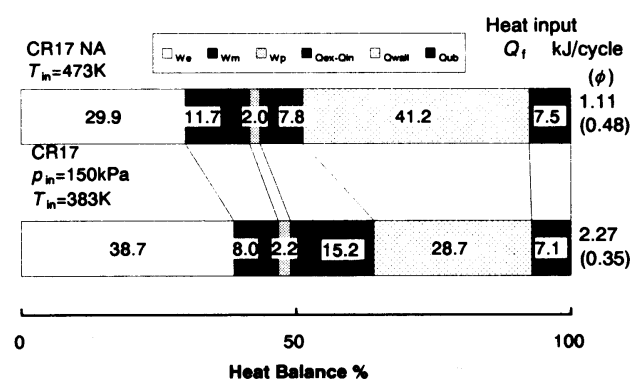

Fig. 11 Heat balance with and without supercharging

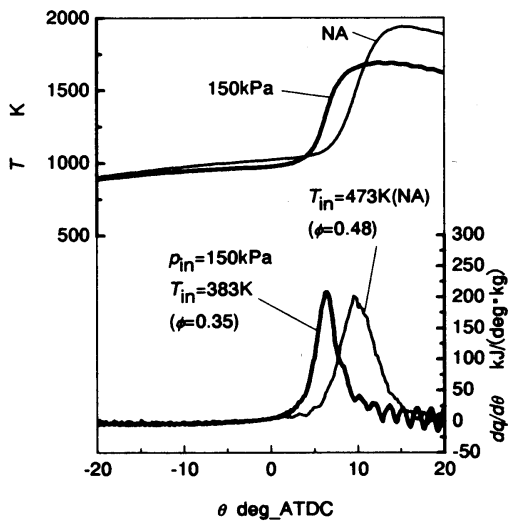

Fig. 12 Courses of heat release rate and temperature

壁面からの泠却損失割合 $Q_{\text {wall }}$ は大幅に減少する．これ によって, 図示仕事(正味仕事 $W_{\mathrm{e}}+$ 摩擦仕事 $W_{\mathrm{m}}+$ 吸排気 仕事 $W_{\mathrm{p}}$ )は改善される．これから，過給によって $\eta_{\mathrm{i}}$ が向 上するのは泠却損失の減少が主因であると考える. 過給 による冷却損失割合減少を理解するため図 12 に筒内平 均ガス温度 $T$ および熱発生率 $d q / d \theta$ の経過を示す. NA および過給いずれにおいても熱発生の開始は上死点後 である. NA では $T_{\text {in }}$ が高く圧縮行程中の温度も上昇す

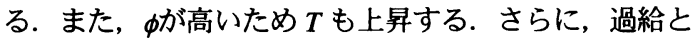
比べると投入熱量も少ない。これから過給における冷却 損失割合の減少は投入熱量增加による冷却損失割合の 減少, 圧縮開始時のガス温度低下による温度履歴の変化 に加えて燃焼時の温度低下 ${ }^{(5)}$ が原因であると考える. 一 方で過給することによって冷却損失は減少するが, その すべてがシリンダ内での有効仕事に変換されるのでは なく, 排気エンタルピー $\left(Q_{\mathrm{ex}}-Q_{\mathrm{in}}\right)$ が増加している. 排気 タービン式過給機の適用を想定した場合, 排気エンタル ピーの增加はタービンで利用できるエンタルピーが増 加することになり, 過給機としては優位に作用すると考 えられる. 天然カスを燃料とする予混合圧縮自着火機関 では運転下限の $T_{\text {in }}$ が高く, 空気あるいは予混合気の加 熱手段が必要となる.しかしながら過給機を適用する場
合は, 圧縮により空気の温度が上昇するため加熱手段は 必要なくなる゙と考えられ, 熱効率および平均有効圧力の 向上，低 NOx とともに過給機を適用する利点の一つで あると考える。

\section{5. 桔}

天然ガス予混合圧縮自己着火機関に外部過給を適用 し，過給圧力を $50 \mathrm{kPa}$ から $150 \mathrm{kPa}$ の範囲で五点設定し て性能および排気特性を詳細に調べ無過給と過給の性 能を比較し以下の知見を得た.

(1) 過給すると運転可能な図示平均有効圧力は向上 し，吸気温度の下限も拡大できる. 過給圧力 $150 \mathrm{kPa}$ において, 最大図示平均有効圧力は $950 \mathrm{kPa}$ となり, 無過給より吸気温度の下限を約 100K 拡大できる.

(2) 過給圧力を $75 \mathrm{kPa}$ から $150 \mathrm{kPa}$ に增すと自己着火 時の圧力は約 6.5MPa から 9.0MPa に上昇するが自己 着火温度は $1000 \mathrm{~K}$ から $1030 \mathrm{~K}$ にまでしか変化しない. (3) 過給において圧縮, 膨張行程のみを考慮した図示 熱効率は最大筒内平均ガス温度が $1700 \mathrm{~K}$ 近辺で極大 值をとる.これは, 着火時期が早期化することによる 冷却損失および燃焼効率が影響していると考える.

(4) 過給圧力を増すと, 最大筒内平均ガス温度が低く ても高い燃焼効率を確保することが可能となり, NOx 排出を抑制しつつ熱効率の改善が可能である.

(5) ヒートバランス解析から, 過給による熱効率の向 上は, 燃焼効率が改善されることに加えて冷却損失の 減少が原因であると考える.

\section{文 献}

(1) R.H.Thring, Homogeneous-Charge Compression-Ignition Engine, SAE Paper No.892068，(1989)

（2）柳原弘道，佐藤康夫，水田準一，均一・広拡散な混合気形成によ る直䠝ティーゼルの燃焼解析，第 13 回内燃機関シンポジウム講 演会論文集，62，(1996)，365-369

(3) 金子 誠, 森川弘二, 伊藤 仁, 最首陽平, 予混合圧縮着火カソ リン機関の可能性, 日本燃泋学会誌, 第 44 巻, 127 号, (2002), 11-18

（4）太田安彦, 古谷正広, ·河野正顥, 小島光高, 自着火制御を施した 天然カス予混合圧縮自着火機関, 自技会論文集, 20004343, (2000), 39-43

(5) 石山拓二, 塩路昌宏, 田中大樹, 中川秀樹, 中井俊作, 筒内直接 噴射による天然カス予混合圧縮着火機関の性能と排気特性, 自技 会講演会前刷集，236，No.46-02，(2002)，15-20

(6) 佐古孝弘, 中井俊作, 守家浩二, 飯田訓正, 天然カス予混合圧縮 自己着火機関の性能および排気特性, 日本機会学会論文集， 70-694, B(2004), 197-203

(7) Morimoto,S., Kawabata,Y., Sakurai,T., Amano,T., Operating Characteristics of a Natural Gas-Fired Homogeneous Charge Compression Ignition Engine(Performance Improvement Using EGR),SAE Paper No.2001-01-1034

(8) 高津戸理恵, 五十崖哲也, 飯田訓正, 予混合圧縮自着火エンジン における n-Butane 然料の自己着火・燃焼過程(外部 EGR が着火お よび燃焼に及ぼす影翬)，日本機会学会論文集，65-638，B(1999), 261-265

（9）鶴島理史，宮本武司，浅海靖男，青柳有三，予混合圧縮着火機関 における圧縮澎張行程期間中のヒートバランス推定の試み, 自技 会講演会前刷集, 163, No.38-00, (2000), 9-12 